\title{
Infertile Lantana camara Cultivars UF-1011-2 and UF-1013A-2A
}

Zhanao Deng ${ }^{3}$

University of Florida, IFAS, Environmental Horticulture Department, Gulf Coast Research and Education Center, 14625 County Road 672, Wimauma, FL 33598

\section{Sandra B. Wilson}

University of Florida, Environmental Horticulture Department, P.O. Box 110675, Gainesville, FL 32611

\author{
Xiaobao Ying \\ University of Florida, IFAS, Environmental Horticulture Department, Gulf \\ Coast Research and Education Center, 14625 County Road 672, Wimauma,
} FL 33598

\section{David M. Czarnecki II',}

University of Florida, IFAS, Environmental Horticulture Department, Gulf Coast Research and Education Center, 14625 County Road 672, Wimauma, FL 33598

Lantana (Lantana L., Verbenaceae) is widely produced and used in the United States, especially in the south. A 2003 survey of the Florida nursery industry, which consisted of more than 5000 nurseries, indicated that $19.0 \%$ of the responding nurseries produced lantana, and the annual sales value of lantana in Florida was estimated to be more than $\$ 40$ million (Wirth et al., 2004). Lantana plants produce showy flowers all year round in frost-free areas and dieback to the ground in the winter in zones $8 \mathrm{~b}$ or lower. They attract butterflies, tolerate harsh environmental conditions, have low maintenance requirements,

Received for publication 7 Feb. 2017. Accepted for publication 9 Mar. 2017.

The development and evaluation of 'UF-1011-2' and 'UF-1013A-2A' were funded in part by USDA hatch projects (Project no. FLA-GCR-005065 and FLA-GCC-005507), the former USDA/Tropical and Subtropical Agriculture Research (TSTAR) program, and the Florida Department of Agriculture and Consumer Service (FDACS) Specialty Crop Block Grant program (Project no. 021747). We thank Gail Bowman, Mary Derrick, Patricia Frey, and Joyce Jones for their technical assistance. We are grateful to Jaroslav Doležel (Laboratory of Molecular Cytogenetics and Cytometry, Institute of Experimental Botany, Olomouc, Czech Republic) who provided pea seeds that were used as the internal standards in flow cytometry analyses. We thank Ball Horticultural Company, Proven Winners North America, LLC, and Riverview Flower Farms, Inc., for trialing 'UF-1011-2' and/or 'UF-1013A-2A' and sharing their observations, fruit count data, and/or photos. Our sincere appreciation also goes to Hugh Gramling for supporting this project and Jianjun Chen, David Clark, Charles Guy, Kevin Kenworthy, and Barry Tillman, and Jim Holm for reviewing this article.

${ }^{1}$ Former graduate student

${ }^{2}$ Current address: Ernst Benary of America, Inc., 195 Paulsen Road, Watsonville, CA 95076

${ }^{3}$ Corresponding author. E-mail: zdeng@ufl.edu. and are easy to propagate. These attributes make lantana highly desirable for use in containers, hanging baskets, and landscapes (Schoellhorn, 2004).

A majority of lantana cultivars found in commercial production and landscape use belong to Lantana camara L. It is native to the West Indies (Sanders, 2001) and was introduced to most tropical regions by 1900 (Howard, 1969). It has escaped cultivation and has hybridized (as pollen donor) with Lantana depressa Small, a now endangered species native to South Florida (Hammer, 2004; Sanders, 1987). Lantana camara has been listed as a Category I invasive species in Florida by the Florida Exotic Pest Plant Council (FLEPPC) (2015). The invasiveness of $L$. camara was evaluated by the University of Florida/Institute of Food and Agricultural Sciences (UF/IFAS) Assessment of Non-Native Plants in Florida's Natural Areas, and it concluded that $L$. camara should not be recommended for commercial production or landscape use in South, Central, and North Florida (UF/IFAS Assessment, 2016). The assessment was based on the evaluation of escaped and naturalized (resident-type) L. camara plants.

A research program was initiated in 2004 at UF/IFAS's Gulf Coast Research and Education Center (GCREC) to identify and develop infertile $L$. camara cultivars. Czarnecki (2011) and Czarnecki et al. (2014) evaluated 26 commercial $L$. camara cultivars in Florida and found out that a majority of them were fertile. There has been a strong need for the development of new infertile $L$. camara cultivars. In response to this need, hundreds of triploid lantana lines were generated and evaluated between 2004 and 2009, and two highly infertile lines were released as new cultivars ('UF-T3' and 'UF-T4') in 2011 (Czarnecki et al., 2012). Subsequently, additional triploid lantana breeding lines were created in 2010 and 2011. Some of these lines showed excellent potential in observational trials at GCREC in 2011-13. A number of the most promising lines were installed in two replicated ground trials in Florida in June 2015. Plants in these ground trials were evaluated for plant performance, flowering, and fruit production, and provided fresh flowers for pollen stainability tests; seeds collected from these plants were subjected to seed viability and germination tests between Fall 2015 and Summer 2016. A separate study was carried out in 2015 to determine the hybridization potential of several most promising lines (low or no seed set, excellent flowering, and performance) with $L$. depressa. From these trials and studies, two of the most promising lines were selected and released as new infertile L. camara cultivars, 'UF-10112' and 'UF-1013A-2A'.

\section{Origin}

'UF-1011-2' (Figs. 1 and 2) was the progeny of a cross between breeding line CAOP-73 $(2 n=4 x)$ and 'Landmark Flame Improved' $(2 n=2 x)$. The cross was made in Fall 2010 at GCREC in Balm, FL, and the cultivar was first selected as an individual plant in Apr. 2012. 'UF-1013A-2A' (Figs. 3 and 4) resulted from a cross between breeding line DROP-25 ( $2 n=$ $4 x$ ) and 'Landmark Flame Improved'. The cross was made in Fall 2010 at GCREC, and the cultivar was initially selected as an individual plant in Apr. 2012. Breeding lines CAOP-73 and DROP-25 were selected by Czarnecki (2011).

\section{Description}

Description of color for plant parts was based on comparison with the Royal Horticultural Society Color Chart (Royal Horticultural Society, 1986). Plants used for describing color and other attributes were propagated from rooted cuttings, grown in 11.4-cm containers $(\approx 600 \mathrm{~mL})$ in a shade house ( $30 \%$ shade) in Balm, FL, and they were 11 weeks old.

Plants of 'UF-1011-2' are shrubs with a mounding growth habit (Fig. 1), $\approx 28 \mathrm{~cm}$

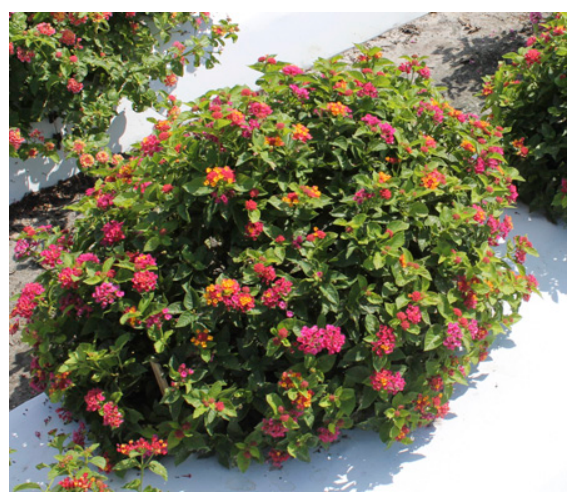

Fig. 1. Plants of 'UF-1011-2' lantana propagated by cuttings, container-grown in a soilless mix for $95 \mathrm{~d}$, and grown outdoors in the ground bed in Balm, FL, for $124 \mathrm{~d}$. Photo was taken at the University of Florida's Gulf Coast Research and Education Center in Balm, FL $\left(27^{\circ} 45^{\prime} \mathrm{N}\right.$ and $\left.82^{\circ} 13^{\prime} \mathrm{W}\right)$ on 14 Oct. 2015 . 


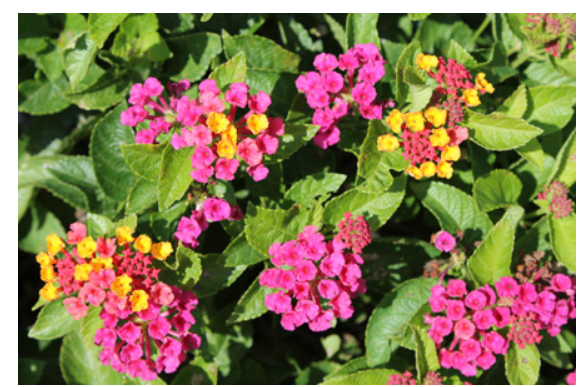

Fig. 2. Flowers and inflorescences of 'UF-1011-2' grown outdoors in ground beds in full sun in Balm, FL.

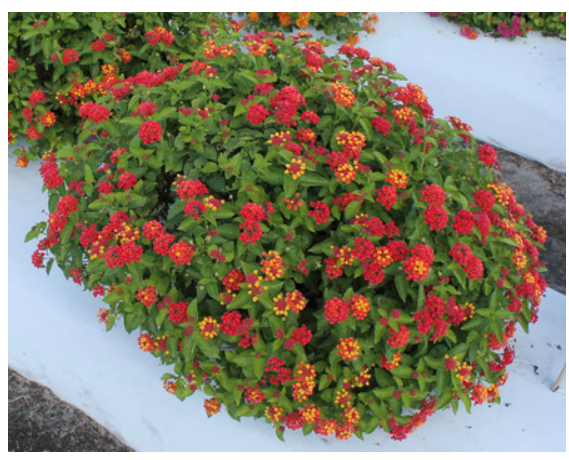

Fig. 3. Plants of 'UF-1013A-2A' lantana propagated by cutting, container-grown in a soilless mix for $95 \mathrm{~d}$, and grown in the ground beds in Balm, FL, for $124 \mathrm{~d}$. Photo was taken at the University of Florida Gulf Coast Research and Education Center in Balm, FL, on 14 Oct. 2015.

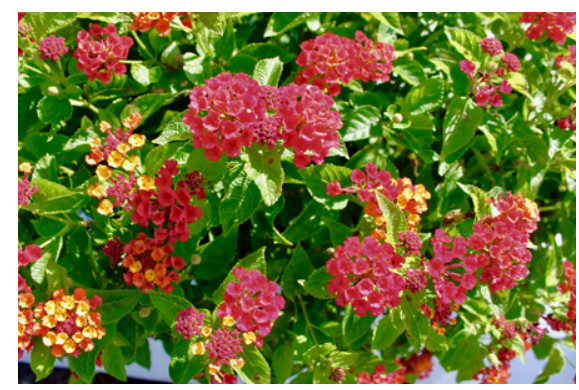

Fig. 4. Flowers and inflorescences of 'UF-1013A-2A' grown outdoors in ground beds in full sun in Balm, FL.

wide and $22 \mathrm{~cm}$ tall. New stems are yellowgreen (RHS 144A), four-sided in cross section, semiwoody, and covered with soft hairs; old stems are close to being round in cross section, light brown (RHS 199B), smooth, and with few hairs. Leaves are opposite, simple, with petioles 1.3 to $2.3 \mathrm{~cm}$ long, and yellow-green (RHS 144A). Mature leaf blades are ovate, 6.5 to $8.1 \mathrm{~cm}$ long, 4.0 to $5.0 \mathrm{~cm}$ wide, with serrated margins (29 to 39 teeth), a broadly truncated base, and an acute apex. The upper leaf surface is green (RHS 137A), covered with soft hairs. The lower surface is green (RHS 137B). Inflorescences (Fig. 2) are umbellike, in the shape of a flattened semisphere, $\approx 4 \mathrm{~cm}$ wide across the top, bearing 26 to 30 flowers. Peduncles are yellow-green (RHS 144A) and 4.5 to $6.5 \mathrm{~cm}$ long. Flowers (Fig. 2) are multicolored, bright yelloworange (RHS 14A) when they open initially, and then turn magenta (RHS 67A). Inflorescences rarely bear fruit (drupes).

The nuclear DNA content of 'UF-1011-2' was determined using a CyFlow $^{\circledR}$ Cube 6 flow cytometer (Sysmex, Partec $\mathrm{GmbH}$, Münster, Germany) and the procedure described by Doležel et al. (2007) and modified by Cao et al. (2014). Pea cultivar Ctirad (Pisum sativum L.), with a nuclear content of $9.09 \mathrm{pg} / 2 \mathrm{C}$, was selected as an internal reference for use in this study. The nuclear DNA content of lantana samples was calculated according to Doležel et al. (2007): sample nuclear DNA content $(\mathrm{pg} / 2 \mathrm{C})=$ internal reference nuclear DNA content (9.09) $\times$ (mean fluorescence value of sample/ mean fluorescence value of internal reference). The ploidy level of 'UF-1011-2' was determined by comparing its nuclear DNA content with the DNA content of known diploid, triploid, and tetraploid lantana cultivars (Czarnecki et al., 2014). The average nuclear DNA content of 'UF-1011-2' is $4.69 \mathrm{pg} / 2 \mathrm{C}$ (Table 1), and it is likely a triploid.

Plants of 'UF-1013A-2A' are shrubs with a mounding growth habit (Fig. 3), about $28 \mathrm{~cm}$ wide and $26 \mathrm{~cm}$ tall. Young stems are yellow-green (RHS 144A), four-sided in cross section, semiwoody, and covered with soft hairs but no prickles; old stems are close to being round in cross section, light brown (RHS 199D), smooth, and with few hairs. Leaves are opposite, simple, with petioles 1.5 to $2.5 \mathrm{~cm}$ long and in yellow-green (RHS 144B). Mature leaf blades are ovate, 6.5 to $8.5 \mathrm{~cm}$ long, 4.6 to $5.7 \mathrm{~cm}$ wide, with serrated margins ( 34 to 44 teeth), a broadly truncated base, and an acute apex. The upper leaf surface is green (RHS 137A), covered with soft hairs. The lower surface is green (RHS 137C). Inflorescences (Fig. 4) are umbel-like, $\approx 4 \mathrm{~cm}$ wide across the top, bearing 28 to 30 flowers, and with yellowgreen (RHS 144A) peduncles 4.5 to $6 \mathrm{~cm}$ long. Flowers (Fig. 4) are bright yellow (RHS 9A) when they open initially and then turn red (RHS 45B). Inflorescences rarely bear fruit. The average nuclear DNA content of 'UF-1013A-2A' is $4.54 \mathrm{pg} / 2 \mathrm{C}$ (Table 1), and it is likely a triploid.

\section{Replicated Ground Trials to Evaluate Plant Fertility and Performance}

Two replicated field trials were conducted in Florida: one at UF/IFAS GCREC in Balm, FL $\left[27^{\circ} 45^{\prime} \mathrm{N}\right.$ and $82^{\circ} 13^{\prime} \mathrm{W}$; USDA hardiness zone 9B (USDA, 2012), and AHS plant heat zone 10 (American Horticultural Society, 1988)], and another at UF/IFAS Indian River Research and Education Center (IRREC) in Ft. Pierce, FL $\left(29^{\circ} 8^{\prime} \mathrm{N}\right.$ and $81^{\circ} 2^{\prime} \mathrm{W}$; USDA hardiness zone $10 \mathrm{~A}$, and AHS heat zone 9-10). The experimental design used in Balm was a randomized complete block with three blocks and two plants per plot. Raised ground beds at GCREC were fumigated with a multipurpose liquid fumigant (Pic-Clor $60^{\circledR}$; active ingredients 1,3 dichloropropene and chloropicrin) at $448 \mathrm{~kg} /$ ha in Feb. 2015 and covered with white-onblack plastic. The experimental design used in Ft. Pierce was a randomized complete block with four blocks and a single plant per plot. Ground beds at IRREC were treated with a preemergent herbicide and covered with black semipermeable groundcover. At each site, 'Pink Caprice' was included as a control. Although a named cultivar, Pink Caprice is very similar to escaped and naturalized lantana plants found along ditches and pastures in Florida (i.e., excessive fruiting, multicolored flowers, and vigorous). Lantana camara cultivar UF-T3 was included as an infertile control (Czarnecki et al., 2012). In addition, there were commercial lantana cultivars with various levels of male and female fertility randomly placed in each block at both sites.

Plants installed at the two sites were propagated at GCREC. Cuttings were taken on 9 Feb. 2015 and rooted in a greenhouse in 128-cell Speedling planter flats (Speedling Inc., Ruskin, FL) filled with a potting substrate and placed under an intermittent mist system. The bottom ends of cuttings were treated with a rooting hormone (Dip ' $\mathrm{N}$ ' Grow, 1:10 dilution, final concentration $0.1 \%$ indole-3-butyric acid and $0.05 \%$ 1-naphthaleneacetic acid) (Dip ' $N$ ' Grow Inc., Clackamas, OR). Rooted cuttings were pinched to 5 to $6.5 \mathrm{~cm}$ heights on 13 Mar. 2015 and to two nodes on 11 May 2015, transplanted on 5 May 2015 to $10.2-\mathrm{cm}$ plastic containers filled with a commercial potting mix (Fafard 3B; Conrad Fafard, Inc., Agawam, MA), and grown in a greenhouse at GCREC (at $15{ }^{\circ} \mathrm{C} /$ night to $33{ }^{\circ} \mathrm{C} /$ day). Container-grown plants were distributed to experimental sites in early June 2015 and transplanted to ground beds in the week of 12 June 2015. Each plant was top-dressed with $\approx 15 \mathrm{~g}$ of a controlled-release fertilizer (Osmocote $^{\circledR}$; 15N-3.9P-10K, 5-6 months; Scotts, Marysville, $\mathrm{OH}$ ) and irrigated through a seepage system at GCREC (Pitts and Smajstria, 1989; twice a day and $1 \mathrm{~h}$ per event) and through drip tapes (Woodpecker pressure compensating emitters; Netafim, Fresno, CA; twice a week, $2 \mathrm{~h}$ per irrigation event, and $3780 \mathrm{~mL} / \mathrm{h}$ ) at IRREC . Fungal disease damages were observed on some plants of 'UF-1011-2' and 'UF-1013A-2A' at IRREC in mid-Aug. 2015. A broadspectrum fungicide/insecticide/miticide containing $70 \%$ clarified hydrophobic extract of neem oil (TriAct ${ }^{\circledR}$ 70; OHP, Inc., Mainland, PA) was applied on 25 Aug. 2015.

\section{Pollen Stainability}

Previous studies have shown that pollen stainability is a good indicator of lantana's male fertility and hybridization potential with L. depressa (Czarnecki, 2011; Czarnecki et al., 2012, 2014; Dehgan and Guy, n.d.). Czarnecki (2011) showed that L. camara cultivars with low pollen stainability 
$(<15 \%)$ had little potential to cross-pollinate L. depressa.

Two pollen-staining experiments were conducted using fresh anthers collected from the previously described field-grown plants. In Expt. 1, newly opened flowers were collected from plants grown in Balm, FL, in late July 2015, and anthers were collected into a $1.5-\mathrm{mL}$ eppendorf tube. Anthers were stained with $10^{-6} \mathrm{M}$ fluorescein diacetate (Sigma-Aldrich, St. Louis, MO) in $0.22 \mathrm{M}$ sucrose solution at room temperatures in the dark for $1 \mathrm{~h}$ (Czarnecki et al., 2014). Stained anthers were transferred onto a microscope grains in the anthers were released by gently tapping and pressing the coverslip and then examined under a fluorescent microscope. Plump round pollen grains fluorescing bright yellowish green light were considered stainable, whereas misshaped, nonfluorescing, or unevenly, lightly fluorescing pollen grains were counted as nonstainable. In Expt. 2, flowers were collected from lantana plants grown in Ft. Pierce, FL, in mid-Aug. 2015. Anther staining and pollen examination were performed as previously described.

The number of pollen grains examined for each lantana cultivar in each staining experiment was between 1094 and 2760 (Table 1). An analysis of variance (ANOVA) and mean separation were conducted using JMP Pro 12.0.1 (SAS Institute, Cary, NC) to compare the pollen stainability slide and covered with a coverslip. Pollen

of 'UF-1011-2', 'UF-1013A-2A', 'UF-T3', and 'Pink Caprice'. The average pollen stainability of 'UF-1011-2' and 'UF$1013 \mathrm{~A}-2 \mathrm{~A}$ ' was $9.7 \%$ and $3.0 \%$, respectively, comparable to the pollen stainability of 'UF-T3'. The average pollen stainability of 'Pink Caprice' was 73.1\% (Table 1), similar to previous results (Czarnecki et al., 2014). These results indicate that the pollen stainability (or male fertility) of ' $U F$ 1011-2' and 'UF-1013A-2A' was reduced by at least $85 \%$ from that of 'Pink Caprice'.

\section{Female Fertility}

Previous studies have indicated that fruit (seed) production per peduncle and seed germination or seedling emergence are the primary factors determining lantana's female fertility and that it is possible to factor these two characteristics into a female fertility index (FFI) by multiplying fruit production per peduncle and seed germination (Czarnecki, 2011; Czarnecki et al., 2012).

Fruit production per peduncle. Fruit production data were regularly collected from field-grown plants in Balm and Ft. Pierce. In each round of fruit harvesting, 20 peduncles were randomly sampled from each plant in the replicated field trials, and drupes on peduncles were counted. Four harvests were made for each plant at each experimental site; thus, in each fruit harvest, $\approx 120$ peduncles were sampled for each cultivar grown in

Table 1. Nuclear DNA content, likely ploidy level, and pollen stainability of 'UF-1011-2' and 'UF-1013A2A' and two checks, 'UF-T3' and 'Pink Caprice', grown in Balm and Ft. Pierce, FL, in full sun in 2015.

\begin{tabular}{|c|c|c|c|c|c|c|c|}
\hline \multirow[b]{2}{*}{ Cultivar } & \multirow{2}{*}{$\begin{array}{c}\text { Nuclear DNA } \\
\text { content } \pm \text { SD (pg/2C) }\end{array}$} & \multirow{2}{*}{$\begin{array}{c}\text { Likely } \\
\text { ploidy level }\end{array}$} & \multicolumn{2}{|c|}{$\begin{array}{l}\text { Pollen grains } \\
\text { examined (no.) }\end{array}$} & \multicolumn{3}{|c|}{$\begin{array}{c}\text { Pollen } \\
\text { stainability }(\%)^{z}\end{array}$} \\
\hline & & & Expt. 1 & Expt. 2 & Expt. 1 & Expt. 2 & $\overline{\text { Avg }}$ \\
\hline UF-1011-2 & $4.69 \pm 0.15$ & $3 \times$ & 1,684 & 1,563 & $10.0 \mathrm{~b}$ & $9.4 \mathrm{~b}$ & 9.7 \\
\hline UF-1( & & $3 x$ & 2,275 & 1,759 & $2.2 \mathrm{~d}$ & $3.7 \mathrm{c}$ & 3.0 \\
\hline UF-7 & & $3 x$ & 2,760 & 1,752 & $5.3 \mathrm{c}$ & $4.9 \mathrm{c}$ & 5.1 \\
\hline Pink Caprice & $6.25 \pm 0.17$ & $4 \times$ & 1,094 & 1,271 & $70.8 \mathrm{a}$ & $75.3 \mathrm{a}$ & 73.1 \\
\hline
\end{tabular}

${ }^{\mathrm{z}}$ Anthers used in Expt. 1 were collected from plants grown in ground beds in full sun in Balm, FL, and stained on 22 July 2015; anthers used in Expt. 2 were collected from plants grown in the replicated field trials in Ft. Pierce, FL, and stained on 13 Aug. 2015. Pollen stainability data were arcsine-transformed before analysis of variance was performed. Means with the same letter within the column are not significantly different by the LSD procedure at $P<0.05$.
Balm, and $\approx 80$ peduncles were sampled for each cultivar grown in Ft. Pierce. Four harvests in Balm were made on 17 Aug., 14 Sept., 16 Oct., and 18 Nov. 2015, respectively, and four harvests in Ft. Pierce were made on 12 Aug., 10 Sept., 14 Oct., and 11 Nov. 2015, respectively. An ANOVA and separation of mean fruit production values were conducted using the JMP Pro 10.0.2 to compare the fruit production of 'UF-1011-2' and 'UF-1013A-2A' with that of 'UF-T3' and 'Pink Caprice'.

'Pink Caprice' produced the largest number of drupes among all entries in the two trials (Table 2). Each peduncle bore an average of 7.941 drupes in Ft. Pierce and 10.313 drupes in Balm, with an overall average of 9.127 across the two sites and four harvests. The number of drupes 'UF-T3' produced per peduncle ranged from 0 to 0.100 and averaged to 0.043 across the two sites and over 4 months (Table 2). The number of drupes per peduncle for 'UF-10112 ' ranged from 0 to 0.125 and averaged to 0.033 across the two sites and over 4 months (Table 2). The number of drupes per peduncle for 'UF-1013A-2A' ranged from 0 to 0.050 and averaged to 0.015 across the two sites over 4 months (Table 2). The level of fruit production in 'UF1011-2' and 'UF1013A-2A' represented $>99 \%$ reduction from the fruit production of 'Pink Caprice'. 'UF-1011-2' and 'UF-1013A-2A' showed low levels of fruit production similar to 'UF-T3'.

Seed germination. Mature drupes were collected from each plant in the previously described experiments. Seeds were extracted, cleaned, and air-dried at each test site and germinated at IRREC. Owing to having few seeds for 'UF-1011-2', 'UF-1013A2A', and 'UF-T3', seeds from four harvests at each site were combined before germination. Seeds were germinated as previously described by Czarnecki et al. (2012). Germination of seeds was monitored every other day for $60 \mathrm{~d}$. A seed was considered germinated if radicle emergence was $2.0 \mathrm{~mm}$ or greater. Seeds were removed after germination to prevent inaccurate data collection.

Table 2. Fruit production, seed viability, seed germination, and female fertility of 'UF-1011-2' and 'UF-1013A-2A', and two checks ('UF-T3' and 'Pink Caprice') grown outdoors in ground beds in full sun at two sites in Florida (2015).

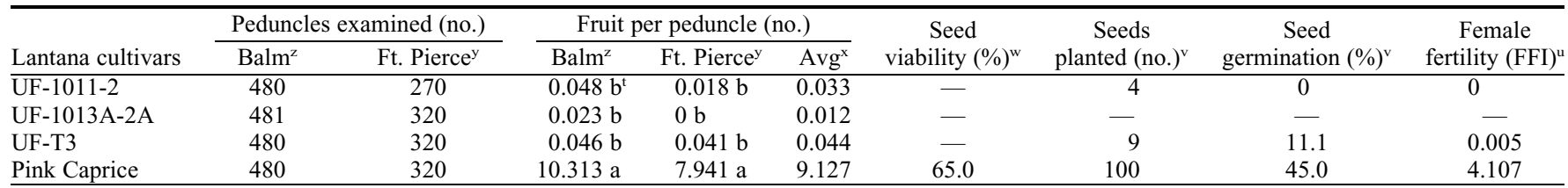

${ }^{\mathrm{z}}$ Number of peduncles randomly sampled on six plants in three blocks in Balm, FL, over 4 months in 2015, and mean fruit production values of the sampled peduncles, including both mature and immature fruit.

${ }^{\mathrm{y}}$ Number of peduncles randomly sampled on four plants in four blocks in Ft. Pierce, FL, over 4 months in 2015, and mean fruit production value of the sampled peduncles, including both mature and immature fruit.

${ }^{\mathrm{x}}$ Average of fruit production per peduncle of two sites (Balm and Ft. Pierce).

${ }^{\mathrm{w}}$ Average seed viability of 100 seeds (two replicates of 50 seeds from Balm and Ft. Pierce sites) determined by the Midwest Seed Services (Brookings, SD). Seed viability tests were not performed for 'UF-1011-2', 'UF-1013A-2A', and 'UF-T3' because of insufficient seed production.

${ }^{\mathrm{v}}$ Seed germination was conducted at the Indian River Research and Education Center in Ft. Pierce, FL, beginning 2 Feb. 2016 and for $60 \mathrm{~d}$. There were four or nine seeds available for 'UF-1011-2' and 'UF-T3', respectively, and no seeds available for 'UF-1013A-2A'. One-hundred seeds of 'Pink Caprice' (50 from Ft. Pierce and 50 from Balm) were tested for seed germination.

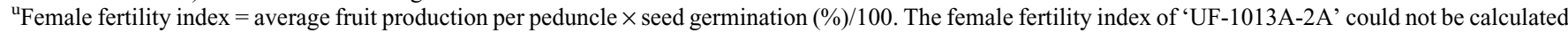
because it did not produce mature seeds. It was expected that the female fertility index of 'UF-1013A-2A' would be close to zero.

${ }^{\mathrm{t}}$ Means with the same letter within a column are not significantly different by the LSD procedure at $P<0.05$. 
Seeds of 'Pink Caprice' also were sent to a commercial seed-testing laboratory (MidWest Seed Services, Inc., Brookings, SD) for seed-viability tests. The distal end of the cotyledon of each seed was cut off, and seeds were stained overnight at $30{ }^{\circ} \mathrm{C}$ in $1.0 \%$ tetrazolium (2,3,5-triphenyl chloride). Seeds were considered viable if the entire embryo stained evenly. 'UF-1011-2', 'UF-1013A2A', and 'UF-T3' produced few or no seeds at either site and were not subjected to viability tests.

Seeds of 'Pink Caprice' showed an average of $65.0 \%$ viability and germinated readily, with an average germination percentage of $45.0 \%$ in $60 \mathrm{~d}$ (Table 2). For 'UF-T3', a total of seven and two seeds were collected from the Balm and Ft. Pierce trials, respectively. One of the nine seeds germinated, resulting in an $11.1 \%$ germination rate. For 'UF-1011-2', four seeds were collected from plants at the Balm site, and no seeds were collected at the Ft. Pierce site. None of the four seeds germinated (Table 2). 'UF-1013A2A' plants at both the Balm and Ft. Pierce sites did not produce mature seeds over 4 months, and no seed germination data were available for 'UF-1013A-2A' (Table 2).

Female fertility index (FFI). FFI for 'UFT3' and 'UF-1011-2' was 0.005 and 0 , respectively (Table 2). Because of a lack of seed germination data, it was not possible to calculate FFI for 'UF-1013A-2A'. However, based on its triploidy and extremely low fruit production, it was expected that the FFI for 'UF-1013A-2A' would be similar to that of 'UF-1011-2' and close to 0. FFI for 'Pink Caprice' was 4.107 (Table 2), similar to previously reported values (Czarnecki et al., 2014) and indicating an extremely high level of female fertility.

\section{Plant Growth, Performance, and Flowering}

Beginning mid-Aug. $2015[\approx 2$ months post transplanting (MPT)] and continuing through mid-Nov. 2015 ( $\approx 5$ MPT), plants grown at the two sites were evaluated monthly for plant performance on a scale of 1 to 5 , with 1 = few branches, open canopy, lacking vigor, 3 = performing fairly well and acceptably as ornamental plants, and $5=$ full plants, dense canopy, desirable shape and color, very attractive. Flower intensity was also rated monthly on a scale of 1 to 5 , with $1=0 \%$ to $20 \%, 2=21 \%$ to $40 \%, 3=41 \%$ to $60 \%, 4=61 \%$ to $80 \%$, and $5=81 \%$ to $100 \%$ of the maximum flower coverage. At the first (2 MPT) and last evaluation (5 MPT), plant height and width in two directions were measured. Data on plant performance, flower intensity, and plant growth were analyzed using the JMP Pro 12.0.1 to determine significance of differences among cultivars. When differences were significant, mean separation was performed using least significant difference (LSD).

'UF-1011-2'. Plants of 'UF-1011-2' grown in Balm were significantly shorter and smaller than plants of 'Pink Caprice'
(Table 3). By 2 MPT, 'UF-1011-2' plants were $40.0 \%$ shorter and $48.6 \%$ narrower than 'Pink Caprice' plants; by 5 MPT, 'UF-10112' plants were $48.8 \%$ shorter and $59.1 \%$ narrower. Plants of 'UF-1011-2' in Balm received 3.2 to 3.5 on plant rating, which was higher than 'Pink Caprice's plant ratings in one of the four evaluations (Table 3). Flower ratings of 'UF-1011-2' ranged from 1.3 to 3.8 , higher than 'Pink Caprice' ratings in two out of four evaluations (Table 3 ).

Compared with 'UF-T3', 'UF-1011-2' plants grown in Balm were $21.2 \%$ narrower by 2 MPT, and were $23.6 \%$ shorter and $27.9 \%$ narrower by 5 MPT (Table 3). Plants of 'UF-1011-2' in Balm received higher plant ratings and higher flower ratings than plants of 'UF-T3' in two out of four evaluations (Table 3). In one evaluation, 'UF-1011-2' received a lower flower intensity rating than 'UF-T3'.

When trialed in Ft. Pierce, 'UF-1011-2' also showed a much smaller stature than 'Pink Caprice' (Table 3), consistent with the differences in plant height and width observed in Balm. Plants of 'UF-1011-2' in Ft. Pierce received plant ratings (2.6 to 3.4 ) similar to plants of 'Pink Caprice' in three evaluations, a lower rating in one evaluation, and lower flower ratings in two evaluations (Table 4). 'UF-1011-2' received similar plant ratings and flower intensity ratings to 'UF-T3'.

'UF-1013A-2A'. Plants of 'UF-1013A$2 \mathrm{~A}^{\prime}$ ' grown in Balm were significantly shorter and smaller than plants of 'Pink Caprice' (Table 3). By 2 MPT, plants of 'UF-1013A$2 \mathrm{~A}^{\prime}$ were $28.9 \%$ shorter in height and $49.8 \%$ narrower in width than those of 'Pink Caprice'. By 5MPT, plants of 'UF-1013A-2A' were $39.9 \%$ shorter in height and $57.4 \%$ narrower in width than those of 'Pink Caprice'. 'UF-1013A-2A' grown in Balm was also smaller than 'UF-T3' in plant width: $23.7 \%$ to $25.0 \%$ narrower by 2 and $5 \mathrm{MPT}$ (Table 3).

'UF-1013A-2A' received 3.3 to 4.0 on plant ratings, which was the highest among all four cultivars and higher than the plant rating scores of 'Pink Caprice' or 'UF-T3' in three out of four evaluations (Table 4). Flower intensity ratings of 'UF-1013A-2A' were 1.0 to 4.3 , which were the highest in the first three evaluations, and higher than the ratings of 'Pink Caprice' in three evaluations and higher than the ratings of 'UF-T3' in two evaluations (Table 4). 'UF-1013A-2A' produced few flowers in Nov. 2015 and received a lower flower intensity score than 'Pink Caprice' or 'UF-T3'.

When grown in Ft. Pierce, 'UF-1013A$2 \mathrm{~A}^{\prime}$ was significantly shorter and smaller than 'Pink Caprice' as well (Table 3): $36.3 \%$ shorter in plant height and $63.1 \%$ narrower in plant width than 'Pink Caprice' by 2 MPT. By 5 MPT, 'UF-1013A-2A' was $54.6 \%$ shorter in plant height and $64.5 \%$ narrower in plant width than 'Pink Caprice'. Plants of 'UF-1013A-2A' were also 35.5\% and $38.8 \%$ narrower than plants of 'UF-T3' by 2 and 5 MPT, respectively (Table 3 ).

Plant rating scores of 'UF-1013A-2A' grown in Ft. Pierce ranged from 2.0 to 3.8, which were lower than the scores of 'Pink Caprice' in three evaluations and higher than the scores of 'Pink Caprice' in one (the last) evaluation (Table 4). 'UF-1013A-2A' shared similar plant ratings with 'UF-T3' in all four evaluations. Flower intensity ratings for ' $U F$ 1013A-2A' grown in Ft. Pierce were between 1.8 and 3.0 (Table 4). They were similar to 'Pink Caprice' ratings in two evaluations and lower in the other two evaluations. 'UF1013A-2A' shared similar flower intensity ratings with 'UF-T3' in all four evaluations.

\section{Hybridization Potential with $L$. depressa after Hand Pollinations}

Hand-pollination experiments were performed in a greenhouse at GCREC in June and July 2015 to assess the hybridization potential of 'UF-1011-2' and 'UF-1013A$2 \mathrm{~A}$ ', as a male or female parent, with $L$. depressa. 'UF-T3' and 'Pink Caprice' were included in the hand-pollination experiments as an infertile and a fertile control, respectively. Stock plants of all lantana cultivars and $L$. depressa were grown on metal benches in gallon plastic containers (Classic

Table 3. Plant height and width of 'UF-1011-2', 'UF-1013A-2A', 'UF-T3' (infertile control), and 'Pink Caprice' (fertile control), grown at the Gulf Coast Research and Education Center (GCREC) in Balm, FL, or at the Indian River Research and Education Center in Ft. Pierce, FL, in ground beds in full sun in Summer (2 months post transplanting) and Fall 2015 (5 months after transplanting).

\begin{tabular}{|c|c|c|c|c|c|}
\hline \multirow[b]{2}{*}{ Trial site } & \multirow[b]{2}{*}{ Cultivar } & \multicolumn{2}{|c|}{ Plant ht $(\mathrm{cm})^{\mathrm{z}}$} & \multicolumn{2}{|c|}{ Plant width $(\mathrm{cm})^{\mathrm{z}}$} \\
\hline & & $2 \mathrm{MPT}$ & $5 \mathrm{MPT}$ & $2 \mathrm{MPT}$ & $5 \mathrm{MPT}$ \\
\hline \multirow[t]{4}{*}{ Balm } & UF-1011-2 & $35.7 b^{y}$ & $45.7 \mathrm{c}$ & $52.9 \mathrm{c}$ & $86.7 \mathrm{c}$ \\
\hline & UF-1013A-2A & $42.3 \mathrm{~b}$ & $53.7 \mathrm{bc}$ & $51.7 \mathrm{c}$ & $90.2 \mathrm{c}$ \\
\hline & UF-T3 & $39.7 \mathrm{~b}$ & $59.8 \mathrm{~b}$ & $67.8 \mathrm{~b}$ & $120.3 \mathrm{~b}$ \\
\hline & Pink Caprice & $59.5 \mathrm{a}$ & $89.3 \mathrm{a}$ & $103.0 \mathrm{a}$ & $211.7 \mathrm{a}$ \\
\hline \multirow[t]{4}{*}{ Ft. Pierce } & UF-1011-2 & $27.8 \mathrm{c}$ & $41.4 \mathrm{c}$ & $46.1 \mathrm{c}$ & $72.9 \mathrm{c}$ \\
\hline & UF-1013A-2A & $36.3 \mathrm{~b}$ & $42.0 \mathrm{c}$ & $40.8 \mathrm{c}$ & $76.5 \mathrm{c}$ \\
\hline & UF-T3 & $42.0 \mathrm{~b}$ & $68.0 \mathrm{~b}$ & $63.3 \mathrm{~b}$ & $124.9 \mathrm{~b}$ \\
\hline & Pink Caprice & $57.0 \mathrm{a}$ & $92.5 \mathrm{a}$ & $110.5 \mathrm{a}$ & $215.3 \mathrm{a}$ \\
\hline
\end{tabular}

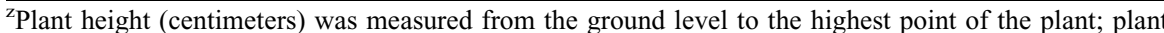
width (centimeters) was measured in two perpendicular directions, and the average of the two widths is reported here.

${ }^{\mathrm{y}}$ Means of three plots (in three blocks) with two subsamples per plot in Balm or means of four plots with a single plant per plot in Ft. Pierce. Means with the same letter within columns within each trial site (not between sites) are not significantly different by the LSD procedure at $P<0.05$. 
300S, $2513 \mathrm{~mL}$; Nursery Supplies Inc., Kissimmee, FL) filled with a commercial soilless mix (Fafard 3B) amended with a controlled-release fertilizer (Osmocote ${ }^{\circledR}, 15 \mathrm{~N}-$ $3.9 \mathrm{P}-10 \mathrm{~K}$ ) at $7.12 \mathrm{~kg} \cdot \mathrm{m}^{-3}$. Stock plants were arranged into three blocks, and in each block, they were randomly placed on benches. The experimental unit was two containerized plants. Temperatures inside the greenhouse ranged from 21 to $33{ }^{\circ} \mathrm{C}$. No supplemental lighting was provided. Plants were dripirrigated twice a day $(\approx 1000 \mathrm{~mL}$ of water a day). Fresh anthers were collected from mature unopened flowers of male parents and applied immediately to the emasculated flowers of female parents. At maturity, fruit produced by pollinated flowers were collected and counted, and seeds were extracted and germinated to determine seed-germination percentages.

As a male parent, 'Pink Caprice' caused an average of $8.6 \%$ fruit set on $L$. depressa (Table 5). When pollinated with L. depressa, 'Pink Caprice' flowers showed $19.7 \%$ fruit set. Seeds from crosses between 'Pink Caprice' and $L$. depressa or vice versa showed $11.1 \%$ or $19.7 \%$ seedling emergence. 'UFT3' caused $0.3 \%$ fruit set on $L$. depressa flowers and showed $0.8 \%$ fruit set after being pollinated with $L$. depressa. None of the seeds emerged as seedlings (Table 5).

A total of $362 \mathrm{~L}$. depressa flowers were pollinated with 'UF-1011-2', and one flower set one fruit, resulting in average fruit set of $0.24 \%$ (Table 5). The fruit contained one seed, and it failed to germinate. When 'UF-1011-2' was used as the female parent, it did not set fruit after having been pollinated with $L$. depressa (Table 5). As a male parent, 'UF-1013A2A' neither caused fruit set on $L$. depressa flowers (Table 5) nor did it set fruit after having been hand pollinated with $L$. depressa. Thus, 'UF-1011-2' and 'UF1013A-2A' did not hybridize or produce viable progeny with $L$. depressa when they were used as a male or female parent in hand pollinations. These data confirm the high level of male and female infertility in 'UF1011-2' and 'UF-1013A-2A' compared with that of 'UF-T3' and 'Pink Caprice'.

\section{UF/IFAS Assessment}

Infraspecific Taxon Protocol (ITP) is an internal tool developed by UF/IFAS to evaluate cultivars (and varieties, hybrids, or subspecies) of resident nonnative invasive species to recommend or not recommend their use in Florida (Lieurance et al., 2016). In July 2016, data on pollen stainability, fruit production, and seed viability/germination of 'UF-1011-2' and 'UF-1013A-2A' and their hybridization potential with $L$. depressa were presented to the UF/IFAS Assessment staff as formal ITP requests. It was concluded that 'UF-1011-2' and 'UF-1013A-2A' are not likely to be a problem species and can be recommended for commercial production and landscape use in Florida (UF/IFAS Assessment, 2016).

Table 4. Plant and flower ratings of 'UF-1011-2', 'UF-1013A-2A', 'UF-T3' (infertile control), and 'Pink Caprice' (fertile control) grown at the Gulf Coast Research and Education Center (GCREC) in Balm, FL, or at the Indian River Research and Education Center in Fort Pierce, FL, in ground beds in full sun from August to Nov. 2015.

\begin{tabular}{|c|c|c|c|c|c|c|c|c|c|}
\hline \multirow[b]{2}{*}{ Trial site } & \multirow[b]{2}{*}{ Lantana cultivar } & \multicolumn{4}{|c|}{ Plant rating ${ }^{\mathrm{z}}$} & \multicolumn{4}{|c|}{ Flower rating ${ }^{y}$} \\
\hline & & Eval. 1 & Eval. 2 & Eval. 3 & Eval. 4 & Eval. 1 & Eval. 2 & Eval. 3 & Eval. 4 \\
\hline \multirow[t]{4}{*}{$\overline{\text { Balm }}$} & UF-1011-2 & $3.2^{\mathrm{NS}}$ & $3.5 \mathrm{ab}^{\mathrm{x}}$ & $3.3 \mathrm{ab}$ & $3.3 \mathrm{a}$ & $1.3 \mathrm{~b}$ & $2.0 \mathrm{a}$ & $3.8 \mathrm{~b}$ & $2.0 \mathrm{a}$ \\
\hline & UF-1013A-2A & 3.8 & $3.8 \mathrm{a}$ & $4.0 \mathrm{a}$ & $3.3 \mathrm{a}$ & $2.5 \mathrm{a}$ & $2.5 \mathrm{a}$ & $4.3 \mathrm{a}$ & $1.0 \mathrm{~b}$ \\
\hline & UF-T3 & 3.2 & $2.7 \mathrm{c}$ & $2.7 \mathrm{~b}$ & $2.9 \mathrm{~b}$ & $2.2 \mathrm{a}$ & $1.3 \mathrm{~b}$ & $2.8 \mathrm{c}$ & $1.8 \mathrm{a}$ \\
\hline & Pink Caprice & 3.5 & $3.0 \mathrm{bc}$ & $3.0 \mathrm{~b}$ & $2.0 \mathrm{c}$ & $1.0 \mathrm{~b}$ & $1.0 \mathrm{~b}$ & $3.0 \mathrm{c}$ & $2.0 \mathrm{a}$ \\
\hline \multirow[t]{4}{*}{ Ft. Pierce } & UF-1011-2 & $3.0 \mathrm{~b}$ & $3.3 \mathrm{ab}$ & $3.4 \mathrm{ab}$ & $2.6 \mathrm{ab}$ & $1.8 \mathrm{~b}$ & $2.3 \mathrm{~b}$ & $3.2 \mathrm{ab}$ & $2.4^{\mathrm{NS}}$ \\
\hline & UF-1013A-2A & $3.0 \mathrm{~b}$ & $2.0 \mathrm{c}$ & $3.0 \mathrm{~b}$ & $2.8 \mathrm{a}$ & $3.0 \mathrm{ab}$ & $1.8 \mathrm{~b}$ & $2.8 \mathrm{~b}$ & 2.0 \\
\hline & UF-T3 & $3.5 \mathrm{~b}$ & $2.3 \mathrm{bc}$ & $3.8 \mathrm{a}$ & $2.0 \mathrm{~b}$ & $2.3 \mathrm{ab}$ & $2.8 \mathrm{ab}$ & $3.5 \mathrm{ab}$ & 3.0 \\
\hline & Pink Caprice & $5.0 \mathrm{a}$ & $4.3 \mathrm{a}$ & $4.0 \mathrm{a}$ & $2.0 \mathrm{~b}$ & $3.8 \mathrm{a}$ & $3.8 \mathrm{a}$ & $4.0 \mathrm{a}$ & 3.0 \\
\hline
\end{tabular}

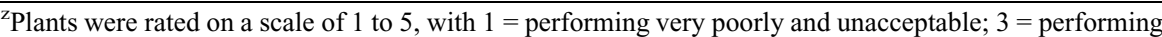
fairly and acceptable as ornamental plants, and $5=$ performing outstandingly and highly desirable. Containerized lantana plants (in 10.4-cm diameter containers) were transplanted to ground plants in Balm on 12 June 2015 and in Ft. Pierce on 10 June 2015, respectively. The four evaluations were performed in Balm on 17 Aug. (Eval. 1), 14 Sept. (Eval. 2), 16 Oct. (Eval. 3), and 18 Nov. (Eval. 4) 2015, respectively, and the four evaluations were performed in Ft. Pierce on 12 Aug. (Eval. 1), 10 Sept. (Eval. 2), 14 Oct. (Eval. 3), and 11 Nov. (Eval. 4) 2015, respectively.

${ }^{\mathrm{y}}$ Flowers were rated on a scale of 1 to 5 , with $1=0 \%$ to $20 \%, 2=21 \%$ to $40 \%, 3=41 \%$ to $60 \%, 4=61 \%$ to $80 \%$, and $5=81 \%$ to $100 \%$ of the maximum flower coverage of the plant. The four evaluations were performed in Balm on 17 Aug. (Eval. 1), 14 Sept. (Eval. 2), 16 Oct. (Eval. 3), and 18 Nov. (Eval. 4) 2015, respectively; the four evaluations were performed in Ft. Pierce on 12 Aug. (Eval. 1), 10 Sept. (Eval. 2), 14 Oct. (Eval. 3), and 11 Nov. (Eval. 4) 2015, respectively.

${ }^{\mathrm{x}}$ Means of three plots with two subsamples per plot in Balm or means of four plots with a single plant per plot in Ft. Pierce. Means with the same letter within columns within each trial site (not between sites) are not significantly different by the LSD procedure at $P<0.05$.

${ }^{\text {NS }}$ Mean values within columns within the trial sites are not significantly different by the LSD test at $P<0.05$.

Table 5. Hybridization potential of 'UF-1011-2' and 'UF-1013A-2A' (Lantana camara) with L. depressa as compared with 'UF-T3' (sterile) and 'Pink Caprice' (fertile).

\begin{tabular}{|c|c|c|c|c|c|c|}
\hline \multirow[b]{2}{*}{ Cultivar } & \multicolumn{3}{|c|}{ L. depressa as the female parent } & \multicolumn{3}{|c|}{ L. depressa as the male parent } \\
\hline & $\begin{array}{c}\text { Flowers } \\
\text { pollinated (no.) }\end{array}$ & $\begin{array}{c}\text { Fruit } \\
\text { set }(\%)\end{array}$ & $\begin{array}{c}\text { Seedling } \\
\text { emergence }(\%)\end{array}$ & $\begin{array}{c}\text { Flowers } \\
\text { pollinated (no.) }\end{array}$ & $\begin{array}{c}\text { Fruit } \\
\text { set }(\%)\end{array}$ & $\begin{array}{c}\text { Seedling } \\
\text { emergence }(\%)\end{array}$ \\
\hline UF-1011-2 & 363 & $0.2 \mathrm{~b}^{\mathrm{z}}$ & 0 & 513 & $0 \mathrm{~b}^{\mathrm{z}}$ & - \\
\hline UF-1013A-2A & 353 & $0 \mathrm{~b}$ & - & 558 & $0 \mathrm{~b}$ & - \\
\hline UF-T3 & 368 & $0.3 \mathrm{~b}$ & 0 & 467 & $0.8 \mathrm{~b}$ & 0 \\
\hline Pink Caprice & 388 & $8.6 \mathrm{a}$ & 11.1 & 452 & $19.7 \mathrm{a}$ & 15.8 \\
\hline
\end{tabular}

${ }^{\mathrm{z}}$ Fruit set data were arcsine-transformed before analysis of variance was performed in JMP Pro 12.0.1. Means with the same letter within the column are not significantly different by the LSD procedure at $P<0.05$.

\section{Conclusion}

Compared with 'Pink Caprice', a $L$. camara cultivar that is close to the species' resident taxon, the pollen stainability of 'UF1011-2' and 'UF-1013A-2A' has been reduced by at least $85 \%$, and fruit production has been reduced by greater than $99 \%$. Typically, these new cultivars did not produce viable seeds, and they did not lead to fruit set or produce viable progeny when used as a male or female parent in hand pollination with $L$. depressa. These high levels of male and female infertility were stable in Balm and Ft. Pierce. These results indicate that 'UF1011-2' and 'UF-1013A-2A' will have little potential to hybridize with $L$. depressa to produce viable interspecific progeny. With a wellbehaved branching, growth habit, and bright flower colors, 'UF-1011-2' and 'UF-1013A$2 \mathrm{~A}$ ' are expected to be a desirable replacement of the existing fertile $L$. camara cultivars.

\section{Availability}

U.S. plant patent applications have been filed for 'UF-1011-2' and 'UF-1013A-2A'.
License agreements for propagation and production of these two lantana cultivars are managed by Florida Foundation Seed Producers (FFSP) Inc. (http://www.ffsp.net), a nonprofit, direct-support organization of the UF. FFSP has used its Invitation to Negotiate (http://www.ffsp.net/itn/) process to solicit proposals from companies interested in an exclusive license for these lantana cultivars. FFSP has awarded an exclusive propagation and production license to Ball Horticultural Company. Ball Horticultural Company will market the two lantana cultivars under its Bloomify ${ }^{\mathrm{TM}}$ brand - Bloomify ${ }^{\mathrm{TM}}$ Rose ('UF-1011-2') and Bloomify ${ }^{\mathrm{TM}}$ Red ('UF-1013A-2A').

\section{Literature Cited}

American Horticultural Society (AHS). 1998. AHS plant heat zone map. 26 July 2016. <http:// ahsgardening.org/gardening-resources/gardeningmaps/heat-zone-map>

Cao, Z., Z. Deng, and M. McLaughlin. 2014. Interspecific genome size and chromosome number variation sheds new light on species classification and evolution of Caladium (Araceae). J. Amer. Soc. Hort. Sci. 49:449-459. 
Czarnecki, D.M., II. 2011. Genetic sterilization and reproductive biology of Lantana camara. Univ. of Fla., Gainesville, PhD Diss.

Czarnecki, D.M., II, A. Hershberger, C.D Robacker, and Z. Deng. 2014. Ploidy level and pollen stainability of Lantana camara cultivars and breeding lines. HortScience 49:1271-1276.

Czarnecki, D.M., II, S.B. Wilson, G.W. Knox, R. Freyre, and Z. Deng. 2012. UF-T3 and UF-T4 Two sterile Lantana camara cultivars. HortScience 47:132-137.

Dehgan, B. and C.L. Guy. (n.d.). Reproductive biology and invasive potential of Lantana camara cultivars. 25 Jan. 2017. <http://portal. nifa.usda.gov/web/crisprojectpages/0191420reproductive-biology-and-invasive-potentialof-lantana-camara-cultivars.html $>$.

Doležel, J., J. Greilhuber, and J. Suda. 2007. Estimation of nuclear DNA content in plants using flow cytometry. Nat. Protoc. 2:2233-2244.
Florida Exotic Pest Plant Council (FLEPPC). 2015. 2015 list of invasive plant species. 21 Aug. 2016. <http://fleppc.org/>.

Hammer, R.L. 2004. The Lantana mess - A critical look at the genus in Florida. The Palmetto 23(1):21-23.

Howard, R. 1969. A check list of cultivar names used in the genus Lantana. Arnoldia 29:73-109.

Lieurance, D., S.L. Flory, and D.R. Gordon. 2016 The UF/IFAS assessment of nonnative plants in Florida's natural areas: History, purpose, and use. 25 Jan. 2017. <http://edis.ifas.ufl.edu/ pdffiles/AG/AG37600.pdf>.

Pitts, D.J. and A.G. Smajstria. 1989. Irrigation systems for crop production in Florida: Descriptions and costs. Univ. of Florida, IFAS, Florida Coop. Ext. Serv. Circ. 821.

Royal Horticultural Society. 1986. RHS colour chart. Royal Hort. Soc., London.

Sanders, R.W. 1987. Identity of Lantana depressa and L. ovatifolia (Verbenaceae) of Florida and the Bahamas. Syst. Bot. 12:44-60.
Sanders, R.W. 2001. The genera of Verbenaceae in the Southeastern United States. Harv. Pap. Bot. 5:303-358.

Schoellhorn, R. 2004. Lantana - summer color that's tough as nails. GPN - Greenhouse Prod. News 14(3):14-16.

United States Department of Agriculture (USDA) Agricultural Research Service. (ARS). 2012. The 2012 USDA plant hardiness zone map. 26 July 2016. <http://planthardiness.ars.usda. gov/PHZMWeb/>.

University of Florida/Institute of Food and Agricultural Sciences Assessment of Nonnative Plants in Florida's Natural Areas (UF/IFAS Assessment). 2016. Lantana camara. 25 Jan. 2017. <http://assessment.ifas.ufl.edu/assessments/ lantana-camara/>.

Wirth, F.F., K.J. Davis, and S.B. Wilson. 2004. Florida nursery sales and economic impacts of 14 potentially invasive ornamental plant species. J. Environ. Hort. 22:12-16. 